\title{
How Non-Heteronormative Mothers Negotiate Meaning: Experiencing and Contextualizing Invisibility
}

\author{
Magdalena Wojciechowska \\ University of Lodz, Poland
}

DOI: http://dx.doi.org/10.18778/1733-8077.16.4.09

\section{Keywords:}

Non-Heteronormative

Motherhood in

Poland; Making

Meaning; Symbolic

Interactionism

\begin{abstract}
This article aims to shed light on how non-heteronormative mothers-whose child had been conceived via artificial insemination of one of them with the sperm of an anonymous donordecode, experience, and make meaning of diverse (symbolic) dimensions of their social invisibility, as well as how their understandings of the category at hand have an impact on projecting and negotiating their roles as mothers (especially in case of those women who did not give birth to their children). Drawing on specific examples from the field, I analyze how-while acting within the context of anxiety exemplifying their non-existing legal status-non-heteronormative mothers construct the image of self against the backdrop of no ready-made role scripts available, as well as strive towards making oneself (socially) visible. The insights at hand are based on data collected during my six-year ethnographic study of planned non-heteronormative motherhood in Poland, where same-sex relationships are not legally recognized.
\end{abstract}

Magdalena Wojciechowska, Ph.D., is an Assistant Professor in the Department of Sociology of Organization and Management, Institute of Sociology, Faculty of Economics and Sociology, University of Lodz. Her research interests lie in studies of members of marginalized social groups.

email address: magdalena.wojciechowska@uni.lodz.pl

\section{Two-Mother Families in Poland: Introductory Remarks}

"Look, they are those dykes!" This is the sentence that Julia, the head of one of the largest departments of an international company from the financial industry, heard from one of the fathers while picking her child up from preschool. She is privately Anna's 
longtime partner and the biological mother of their child, who was born thanks to artificial insemination with the sperm of an anonymous donor. She remembers the day when she heard it very well, as well as the phone conversation she had with Anna a few minutes later. It was the last day when their child went to that preschool. The names of both women are, of course, fictitious, while their story, portraying challenges that two mothers of one child encounter in Poland on a daily basis, is real.

Having instanced the above situation, it should be noted that same-sex couples living in Poland receive no legal recognition, which represents for them both symbolic, as well as practical issues. Their circumstances become even more complicated when they raise a child ${ }^{1}$-like in the case of planned families of women who bring up children together conceived through artificial insemination of one of them with the sperm of an anonymous donor. Why is it so? To begin with, Polish law does not allow for the acquisition of parental rights in relation to a biological child of one's partner by a person of the same sex as the child's parent (formal guardian), nor is there a possibility of adopting a child by same-sex couples. This means that although the biological moth-

\footnotetext{
${ }^{1}$ It is estimated in the introduction to Teczowe rodziny $w$ Polsce (Rainbow Families in Poland) that "data provided by the media speak of over 50,000 children who are raised in Poland by same-sex parents" (Abramowicz 2010:8 [trans. MW]). Still, no information about the source of that information is provided. Meanwhile, a research report drawn up as part of the Rodziny $z$ wyboru w Polsce (Family of Choice in Poland) project refers to the collection of 7028 questionnaires, of which 3038 were qualified for the analysis (Mizielińska, Abramowicz, and Stasińska 2014). "Among the respondents, 9\% declared that they had a child, more than twice as many women (11.7\%) than men (4.6\%)" (Mizielińska, Abramowicz, and Stasińska 2014:130 [trans. MW]). In relation to conceiving a child in a same-sex relationship-“[in] $8 \%$ of cases [concerning the aforementioned $9 \%$ ], the child was conceived during the current relationship with a person of the same sex" (Mizielińska, Abramowicz, and Stasińska 2014:133134 [trans. MW]).
}

er's partner (social mother ${ }^{2}$ ) participates in raising their child, she cannot make any legally-sanctioned decision concerning the child; the offspring is not her heir; in the case of the women's separation, the child will not receive legally-established alimony; and-in the event of the death of the biological mother-the offspring may be legally taken away from the social mother (in light of Polish law the will of the biological mother in this regard-expressed in her testament-may not be taken into account).

How does it affect the everyday lives of women I have met during the project? Having internalized norms and values embraced by the heteronorm framework-embodied and exemplified, for instance, in Polish law-they often adopt a strategy of hiding the nature of their relationship (family) in front of certain people and in certain situations. Why are they acting so? Because of anticipating the possibility of experiencing some form of emanation of homophobia, which-at various levels of meaning-would pose a threat not only to them, but-which they fear the most-to their child. Their anxieties in this respect are fueled, on the one hand, by how such families as theirs are portrayed in everyday Polish discourse-as an aberration. On the other hand, some of the study participants, like Julia and Anna, do not have to go as far as deconstructing the content of casual conversations or Internet comments, since they have experienced its materialization for themselves. The report regarding the "Attitude to People of Homosexual Orientation" (CBOS 2017:4) further contextualizes the situation of those beyond the heteronormative framework in Poland:

\footnotetext{
${ }^{2}$ It should be noted here that while describing the situation of social mothers I refer to them in the empirical parts of this paper as non-biological mothers. It was the research participants' choice to be referred to thusly in potential publications since they believe the term at hand is the closest to their situation in the socio-legal context of Poland.
} 
One sixth of respondents (16\%) regard homosexuality as something normal...Over half of Poles (55\%) treat homosexuality as a deviation from the norm, which should be tolerated, while every fourth respondent (24\%) thinks that it should not be tolerated. The last attitude in this decade is much less frequently expressed than previously... Most Poles are reluctant to extend to homosexual couples norms and rights of heterosexuals. Over the years, however, we have seen some change in this respect. One third of respondents (32\%) are in favor of same-sex couples publicly showing their way of life. Slightly fewer approve of their right to enter into marriages (30\%), and one-ninth (11\%) think that they should have the right to adopt children.

Also, according to a more recent report regarding the attitude of Poles towards homosexual relationships, "While we have observed a slow increase in openness towards gays and lesbians...this trend has slowed down...Significantly more people than in 2017 do not want homosexual couples to publically show their way of life." Also, three-fifths of Poles do not approve of their right to enter into a civil partnership, and there are even more opponents of their right to enter into marriages, not to mention adopting children (CBOS 2019:12 [trans. MW]).

Having the above in mind, when it comes to contextualizing the situation of two-mother families in Poland, it is worth noting that while, on the one hand, diverse cultural messages seem to glorify the role of the mother, framing motherhood as the obvious, and even obligatory, stage of life of every woman, on the other hand-it turns out that such a role is, in fact, reserved for those individuals who are normal (i.e., heterosexuals who follow traditional, preferably catholic, values). Thus, while the heteronormative society can turn a blind eye to certain "flaws" of heterosexual mothers (e.g., their very young age, physical/intellectual disability, being addicted to psychoactive substances, etc.), non-heteronormative motherhood in Poland is socially perceived as, at best, inadequate. Such a view seems to embrace the patriarchal approach to motherhood-reserved for normal women whose sexual orientation will not threaten the proper socialization of the child (see: Majka-Rostek 2014). The above can be seen in terms of a manifestation of social control guarding the traditional order, whose effectiveness is exemplified by the fact that when considering enlarging their family, the women under study undertake an intense emotional and (auto-)identity work aimed at answering the question whether they have a moral right to become mothers at all. As Krzysztof T. Konecki (2018:35) observes:

Auto-work on identity is...part of the motivational process to carry out activities consistent with the identity and sustain it and, in turn, to keep the continuation of these activities. Auto-work on identity appears automatically in connection with a specific, planned, or important action for the individual...Auto-work on identity can be treated as a certain form (quality) of the existence of the mind and the self.

Needless to say, the situation of a social mother seems to be even more complicated. Due to this, she is at risk of experiencing double stigma and double invisibility-not only as a non-heteronormative mother (oxymoron), but also as an outsider involved in raising a child of another woman. The circumstances at hand reflect the heteronormative society's value system which upholds the belief that one child can have only one "real" mother, which seems to complicate further the difficult situation of a social mother raising a child who, in the eyes of Polish law, is not, and simply cannot be, hers-for she faces 
a difficult task of constructing a coherent image of self, piecing together the elements that seem to not have a socio-cultural underpinning.

Not surprisingly, one's personal acquaintance with those beyond the heteronormative framework significantly shapes the way they perceive the rights of such people (see: CBOS 2019)-most probably because they are no longer perceived in terms of an abstract social issue, but as actual people-one's acquaintances, friends, colleagues; in short, someone they know. "Those who know a gay or lesbian, more often than others, perceive this sexual orientation as something normal and express the need for tolerance, while they are less likely to treat it as a deviation that should not be accepted" (CBOS 2017:4). Further, the 2019 survey shows that more than every third respondent (36\%) knows someone of homosexual orientation (CBOS 2019). The above observations resonate, to some extent, with Zimbardo's (2007) insights about cognitive processes-that people tend to fear what they are not familiar with, and that not knowing somebody makes it easier to lose sight of that person's humanity, seeing them instead as, for instance, an abstract social problem-and thus further contextualize the situation of two-mother families in Poland. Thus, although the aim of this article is to shed light on how the anxieties of two mothers of one child residing in Poland contextualize their experiences, it should not be forgotten that the mistrust at hand is, in fact, mutual, and, in this sense, co-constructed by the parties involved-those who assume to be seen as non-normative and the normative society at large, with whose norms the former constantly interact-resulting in creating everyday realities for everyone involved.

In the following empirical sections of the paper, I will focus on one of the parties involved in the co-construction of their everyday realities, and thus explain how-while interacting with the norms they find oppressive, as well as based on the assumptions they make about how they may be seen-two mothers of one child give meaning to their experiences in relation to dealing with finding oneself socially invisible. Also, in the course of subsequent analyses, I will emphasize the situation of those women who did not give birth to their children-for, as discussed earlier, being at risk of experiencing double invisibility and having no ready-made role scripts available, they engage in an intense "auto-work on identity" (Konecki 2018) aimed at "establishing" their roles as mothers.

\section{Normality and Deviance in the Lens of Symbolic Interactionism}

The attempt to describe the experiences of two-mother families in Poland emerges from reflection on constructing social reality (Berger and Luckmann 1966), inscribed in the theoretical framework of symbolic interactionism. For this reason, the analytical emphasis has been placed on how, while interpreting the world around them, the participants give meaning in the process of negotiating their whatness and howness (Kleinknecht 2007). Following Herbert Blumer (1969), I assume that the influence of any element of the reality external vis-à-vis the individual is mediated by a continual process of interpretation, during which one gives their experiences a specific meaning. In this context, human acting emerges in the course of constant construction of meanings, which-as any realized element of social reality-are unstable, since every action, interaction, and phenomenon are continually defined and adapted to the individual's interpretations (Strauss 1959; Prus 1997). Therefore, any description of a certain entity does not exclude re-negotiating it 
concerning other levels of meaning, which exemplifies the (cognitive) perspective of the one who gives meaning rather than the ambiguity of the object at hand. Furthermore, such a perspective allows one to take any action based on suppositions towards the object, whose direction may change in the course of interaction with the one being named (see: Strauss 1959). For this reason, human experience can be seen in terms of social products-emerging and/or ongoing constructs (Prus and Grills 2003).

The above considerations outline the analytical paths that I follow in this paper while attempting to understand the experiences of individuals who, interacting within certain symbolic frameworks, see their situation in the context of acting within undecoded social meanings rather than in terms of "paving the way." For it should be outlined that the conceptual complexity of the situation of non-heteronormative mothers is largely because although the content of specific social roles cannot be equated to a specific set of guidelines that compliance would outline the only proper way of taking a certain role, individual actions are, nonetheless, anchored by the rule of intersubjectivity, which implies that people behave in such a way as if certain universal roles existed (Turner 2001). Thus, one of the major obstacles the participants of the study face on a daily basis is dealing with stigma-being seen (and, due to having internalized specific norms and values, understanding that they, indeed, can be seen) as deviants operating in the so-called normal world.

As Erving Goffman (1986) observes, normality is, for the most part, conceptualized in relation to that which has been socially established as deviant. This indicates the recognition of normality in terms of a certain collective representation of subjective perceptions about how it should be (now, as well as in the future). Thus, one's normality seems to require displaying during social encounters. This is the case as one can attest to being part of a certain community, but also maintain a specific self-image, based on which the individual shapes one's identity being subject to the process of negotiation and verification-precisely during an interaction (Strauss 1959). Therefore, the act of displaying normality can be seen as a mechanism aimed at protecting the social actor from being labeled as deviant-that is, symbolically stigmatized (Goffman 1986). Referring to the issue of constructing and reproducing normality (Berger and Luckmann 1966; Prus and Grills 2003), Erving Goffman (1986) highlights two mechanisms having an impact on the process at hand: 1) the internalization of specific norms and values in the process of socialization and 2) the normalizing social control aimed at "disciplining" the individual accordingly. Still, it should not be forgotten that social actors adapt to certain norms of social life, guided by a variety of motives, by matching the line of their actions with the guidelines provided by their interactional partners. In such context, striving to be labeled normal (insofar as one's stigma is not known or visible, making one discreditable rather than discredited [Goffman 1986]) can be seen as protecting oneself against potential symbolic sanctions. And yet it is worth noting that while, on the one hand, doing so can, indeed, free the individual short-term from the anticipated consequences of disclosing one's deviation from what is considered normal. Acting thusly can also, on the other hand, lead to internal conflict(s) - as "playing the game" contributes to reproducing precisely those norms one finds oppressive in the first place. Exemplification of the above is provided by the situation when the participantsprecisely out of fear of symbolic sanctions-hide the nature of their family, in front of certain people and in certain situations, based on the availability 
heuristic, as well as the norm of monomaternalism (a woman with a child must be the mother). However, giving meaning to such passing practices (Goffman 1986) can prove problematic in the context of building a child's strong self-esteem (which the participants strongly emphasized during interviews). Thus producing numerous dilemmas they face in the course of identity narration-an issue that I will discuss further in the empirical part of the paper.

\section{A Study of Planned Non-Heteronormative Motherhood in Poland-Methodological Note}

Issues discussed in the paper at hand are based on data collected during my six-year ethnographic study of two-mother families in Poland. Among the couples who participated in the study are 21 families $^{3}$ whose child had been artificially conceived (due to intrauterine insemination or in vitro fertilization of one of them with the sperm of an anonymous donor) in the course of their relationship.

Semi-structured interviews, which I conducted in various configurations, were the leading technique of data collection. When meeting a given family for the first time, I interviewed both of the women, unless the couple split up. The next step was to interview the women separately-during our succeeding

\footnotetext{
${ }^{3}$ At the time of our first meeting, the women were aged 2640 , and their children's age varied from 2 months to 6 years (5 couples were expecting). Before deciding to enlarge their families, women were couples from 18 months to 5 years. One of the couples separated before their child reached one year of age, but they still raise the offspring together. It is also worth noting here that all of the couples in the study enjoy both cultural and economic capitals allowing them, in their opinion, to protect themselves, as well as their child, against anticipated emanations of homophobia, including moving to another country (which, due to the lack of sufficient social capital, one of the families did-it was the only family in the study whose relationship, as well as their decision of having a child, was not accepted by their families of origin).
}

meetings. Although I am aware of the limitations of conducting the interviews thusly, my decision to do so was twofold. First, the majority of the research participants insisted on telling their stories in the presence of their partners. This, although can be interpreted in terms of anticipating tension such a meeting may cause, was explained in more pragmatic terms. Since their child was still very young, one person was unable to simultaneously take care of the child and focus on narrating; another thing is that the women perceived such a solution as lucrative for me. Instead of one person, I was able to interview two people, which was to guarantee that no important fact was to be omitted or distorted. This, at the analytical level, allows the researcher to make assumptions regarding the nature of the relationship those women had. Second, being aware that such a way of conducting interviews would allow witnessing how the women relate to their partners, as well as their child, ${ }^{4}$ what, in the context of the study, is extremely valuable, I decided to comply with their request. During the interviews with both partners, I paid special attention to not touch on any sensitive, or potentially so, issues, which, if emerged, were brought to light at the time of individual meetings. Moreover, since most of the couples do not publically reveal the nature of their relationship (in certain situational contexts or in front of certain people), the participants involved have been anonymized. In sum, I have conducted 76 interviews with the women whose child had been conceived in the course of their relationship-30 interviews with

\footnotetext{
${ }^{4}$ The research participants' children (usually toddlers) were present at the time of the interview. Still, none of the women insisted on keeping the interview short. Furthermore, as one of the participants has stated, our meeting was important for her since she viewed it as the opportunity to raise-via potential publications-social awareness in the area of two-mother families in Poland. On the other hand, I do not exclude that such motives could have an impact on the way they constructed their narrations.
} 
both mothers and 46 individual interviews (21 with biological mothers and 25 with social mothers). ${ }^{5}$ The interviews lasted around three to five hours (in case of interviews with both partners) and around one to two hours (in case of individual interviews), and were audio-recorded and transcribed.

The second technique of data collection was overt participant observation, aimed at capturing how the women under study present and practice their family in a visible (both common and institutionalized) social space, as well as how specific social responses to their actions, as interpreted by the women, have had an impact on adapting certain strategies of functioning in the social milieus at hand (such issues were clarified during conversational interviews [Konecki 2000]). Three families allowed me to accompany them in their everyday life activities such as going to the park, to the shopping mall, to the zoo, picking the child up from nursery school, or playing with the child in the yard or at the playground. I have conducted 28 observations lasting around one to three hours, with the notes being taken during or right after the observation.

All data gathered during the course of the study have been analyzed according to grounded theory methodology procedures (Glaser and Strauss 1967; Konecki 2000). Following the procedures of theoretical sampling and constant comparative method, I have been deciding on what data to collect next, as

\footnotetext{
${ }^{5}$ Since one of my aims was to see whether/how the research participants' situation evolved, I intended to interview each of the couples at-a minimum -two points in time. I have interviewed 8 couples twice ( 2 families in 2014 and 2016, 3 couples in 2015 and 2017, and 3 other families in 2016 and 2018) and 4 families 3 times ( 2 families in 2013, 2015, and 2017 and 2 other couples in 2014, 2016, and 2018). Also, although a two-year interval may not seem enough to offer insight into potential shifts, many of the women narrated how and why they had revised their strategies of presenting their family as their child was growing up, and thus becoming a more aware social actor (preschool children).
}

well as where to find them, to understand how various dimensions of the participants' everyday lives are interconnected, and thus construct a theory grounded in the data. Therefore, it should be noted that, at first, the scope of the project was much wider-encompassing the situation of same-sex female and male families in Poland. Still, since during the course of the study the issue of parenting emerged as one of the most important categories for the participants (mostly in the narrations of women, but also in those of men), I followed their lines of verbalized experiences. During the course of the study, I interviewed both planned, as well as reconstructed families. ${ }^{6}$ Still, since the situation of reconstructed families turned out to be quite different from what planned families encounter, for instance, due to the simple fact of the presence of the child's father (or their mother) within institutionalized social spaces (see: Wojciechowska 2020), data obtained from the former mostly served comparative purposes (and are not included in the paper). Furthermore, having conceptualized my research inquiries as exploring the experiences of two mothers of one child residing in Poland, I intended to see whether/how their situation, perceived as marginalized by the study participants, evolves, as their children grow up and thus become a (more) aware interactional actors; or whether/how other contextual, situational, and interactional factors shape their experiences in the area of non-heteronormative motherhood. ${ }^{7}$ The re-

\footnotetext{
${ }^{6}$ Among the reconstructed families were three lesbian couples who raise a child being a biological descendant of one of them (conceived during her marriage ended with divorce). I also interviewed one gay couple where one of the partners has a child being raised by his ex-wife.

${ }^{7}$ During the course of the study, I had a chance to converse with some of the participants' family members, as well as observe how they interact (i.e., the mother of one of the participants accompanied us-out of curiosity-during one of the first observations), which enabled me to further contextualize the line of my analyses. Still, since I aimed to reconstruct the perspective of two women who decided to enlarge their family (and conver-
} 
sults of thusly conducted explorations-concerning one of the analytical categories, that is, dealing with conceptual invisibility (and the processes thereof), are presented in the subsequent sections of the paper.

\section{Dealing with Stigma in the Context of Conceptual Invisibility}

I remember, for example, but it was before we moved, in the elevator, I mean, a neighbor said to M. [interviewee's son] in the elevator something like, "Hey, little guy! Don't you have a nice auntie?" And, you know, it wasn't like rude or something, I don't know, discriminating, but... You know, it's just that they have to name me in some way. That is, it seems to me that it's in our nature to call things by their names, and, when it comes to me, well, there's no name that would apply here, right? [Cynthia, non-biological mother]

The above quote represents an apt manifestation of the socio-cultural norm of monomaternalism, which can be seen in terms of the ideological doctrine that "resides at the intersection of patriarchy (with its insistence that women bear responsibility for biological and social reproduction), heteronormativity (with its insistence that a woman must pair with a man, rather than other women, in order to raise children successfully), capitalism (in its conception of children as private property), and Eurocentrism (in its erasure of polymaternalism in other cultures and historical periods)" (Park 2013:7). In this sense, the above interpretation of one's situation-“it's in our nature to call things by their names, and, when it comes to me, well, there's no name that would apply here, right?"-directly points to a conceptual gap indicating potential difficulties in understand-

sational interviews [see: Konecki 2000] with their next of kin did not provide the context of theory discovery), while collecting the data, I decided to focus on the issue at hand. ing the socially unconceptualized figure of the other mother. Due to such conceptual invisibility-in a situation of decoding her status towards the childthe woman is, most likely, to be seen as different, thus constituting a symbolic threat to the "known" and-more importantly-normal (Goffman 1986). Of course, having internalized the frame of meaning at hand, the participants not only deal with keeping their status of (only) "discreditable" (Goffman 1986), but they also strive to build a coherent image of self, often based on such meanings that they know, that is, conceptually available ones.

The above considerations outline the analytical paths that I follow in the next part of the article-in an attempt to illustrate how non-heteronormative mothers negotiate the sense and meaning(s) of their role(s).

\section{Everyday Living in the Context of Anxiety: Being Nobody in the Light of Law}

The heading context of anxiety, socially, culturally, and legally underpinned, is one of the sensitizing concepts that not only outlined potential areas of research, but also proved to be an important frame of meaning in the process of contextualizing the experiences of non-heteronormative mothers-especially of those women who did not give birth to their children. In this sense, the context at hand stands for a conceptual representation of the (emotional) state that arises among the interviewees in a situation of conceptualizing oneself at the legal level, that is, in the context of one's (formal) impuissance to regulate their status towards both the partner, as well as the child. Such a conceptual location is relativized by the women with whom I have spoken both to issues they find-simply-problematic (e.g., when a child is ill only the biological mother is entitled to get sick leave), but also to matters of much greater impor- 
tance-for example, when their anxiety is accumulated and drains from one simple question-What happens when the biological mother is gone? ${ }^{8}$

I'm actually scared of the future, especially when I think about such matters that one of us could pass away, and such fears that I have are, so to speak, so very real in our situation, I mean, in Poland, where nothing changes for the better. Things only get worse here. [Kate, non-biological mother]

The verbalized experience of fear seems to have its foundation-above all-in anticipating potential difficulties most of the non-heteronormative mothers are expecting to face at some point. For this reason-to elucidate the issue at hand as experienced by the women under study-I give voice to Agatha who brought up the above-mentioned concerns in the context of painful and difficult interactional episodes she experienced as the postoperative complications of her pregnant partner induced the premature arrival of their child into the world.

Agatha: I was looking for her like everywhere. I got to the hospital, I went to the delivery ward, but they told me she wasn't there. Somebody made me leave. I didn't know what was going on, so I kept on asking about her 'cause I knew she was there...I heard her, I knew she must have been there, in this hospital room 'cause I heard her screaming...One lady approached me and asked who I was, so I told her I was entitled [had legal competence] to be informed about Diana's health condition. And she said: "Then show it to me." I tried to explain it was in their files, right, but she only replied: "Sorry, I have no time for this," and she shut the door to the other ward. I didn't know

\footnotetext{
${ }^{8}$ Fear of the death of one of the mothers of the couple can also be seen in terms of an indicator of one's basic experience, that is, "fundamental anxiety" (Schütz 1962).
}

what else to do. I was standing there, banging on the door. $[\ldots]$

Me: Were you allowed to see Adam?

Agatha: Not a chance! Diana told me she had authorized me to see our son, so I went to the nurses' room and asked them to let me in. Again, they told me I was not a family member so I wouldn't be able to see him. "Even grandparents can't see their grandchildren, only parents." I told them about the authorization, "Then go to the doctor's office." And so I went to the doctor and explained the situation all over again. She said that if such authorization has been written, I would be let in, but she was too busy to look for it... So I left her office and went back to the nurses' room, and I simply told them I have cleared things up, right. And, I went there to see Adam.

The above excerpt-consisting of two utterances aimed at illustrating the (legal) non-existence of non-biological mother(s) within the institutionalized social space-represents, of course, an extreme example of a situation that may happen to a non-heteronormative family. Still, it was not brought up here to stir emotions, but to draw attention to two analytical paths emerging from the verbalized experiences. First, it is worth taking a closer look at the issue of refusing the woman to see her child-to which the biological mother authorized her partner. Leaving aside the issue of potential motives behind so doing, what should be elucidated is the difficult and ambiguous situation of a non-biological mother-not being recognized in Polish law as a person having any right to her child, she made sure that her partner completed the formalities that would authorize her to see her offspring, and yet this cannot happen, since the decision-maker in this regard claims to have other issues to be covered. Second, such experiences, especially if they become interiorized, can lead to one's functioning within the closed context of anxiety produced in the 
aftermath of one's (empirically confirmed) inability to extinct fears about the child's future when the biological mother is-at different levels of meaning-no longer around. The following excerpts of women's narrations further contextualize the issue at hand.

We live together, we raise our son, but nobody would ask if we are a loving family 'cause it doesn't matter, you know. I practically don't exist. I need Anna's authorization to do things any parent should be able to do. I can't even take John to the doctor because I cannot make any decision regarding my own son. I changed my last name to make things easier, I have all possible kinds of authorizations, and we both wrote our last will, but life is unpredictable, you know. I don't know what may happen in, I don't know, a week's time, you know. To be honest, I'm freaking out. I really don't know what our life would look like if something happens to Anna. [Barbara, non-biological mother]

If something would happen to me, right, my family knows that fighting for parental rights with Mary can't cross their mind...We have all kinds of documents involving a notary public, but this is not enough! I mean, they [attorneys] have no knowledge as to how to secure us. [Susan, biological mother]

Everyday functioning within the context of anxiety is highlighted in a similar vein by another non-biological mother, whose situation is further complicated since she split up with her partner before their child reached one year of age. Women continue to raise their offspring together, however-despite having worked out how they would share custody-the non-biological mother continues to worry whether her partner's will in this regard is, indeed, irrefutable.

As I said, Kate wrote her last will. If something would happen to her before Anne is of legal age, I am to take care of her, that's Kate's will. She also told her parents she wants me to be Anne's legal guardian. I think they are okay with this, but, yeah, you can never be sure, right? We're not together anymore, and I don't see them so often nowadays, so... The thing is, Kate's attorney told her she can write her last will and name me as Anne's legal guardian, but it doesn't mean a thing. Anne is not an object, so Kate's will doesn't apply here. [Anna, non-biological mother]

As reflected in the above narrations, striving for some form of regulation of their uncertain everyday living, the women under study undertake two kinds of attempts to normalize their situation, thus trying to manage (minimize) the context of anxiety in which they operate. On the one hand, they explore the possibilities they have in the area of formal "recognition" of their rights (and duties) towards their child that can be granted by (marginalizing) Polish law (which, in this sense, can be seen as one of the emanations of specific socio-cultural context which demarcates what is normal from what is not). Still, most of the non-heteronormative mothers under study referred to the issue of poorly developed institutional background, as well as insufficient knowledge of legal advisors, which-exemplifying the gap in Polish legal regulations-confirms their conceptual invisibility in various dimensions of social life. The situation at hand encourages women to resort to informal solutions, which-based on formally unrecognized "social contracts" with their families of origin-seem to serve (above all) symbolic purposes-that of comforting the women, as well as making them visible among their closest interactional circles. Such informal arrangements with their families were made by the majority of the informants, which can be seen in terms of seeking a sense of ontological security (see: Giddens 1991; Konecki 2018). However, it is worth noting here that this was possible due to spe- 
cific (good) relations most of them declared to have with their families of origin. For the vast majority of women enjoyed both acceptance and support from their closest interactional circles. Still, this situation looks different in the case of a couple-the only one in the sample-who have practically no contact with their next of kin (which is due to the lack of acceptance of their deviant relationship). Their inability to formally regulate the situation of the family, as well as to proceed with informal arrangements translates into considering-as a possible solution-emigrating to a country where they would be seen (and recognized) as a real family-just the way they understand their situation.

It may sound a bit dramatic, right, but our situation is that we're all alone. I mean-ALONE. You know, Magda, how my or Julia's family situation looks like, right? So you know that there's no one we can turn to. If something happens, if I have an accident, what then? What will she do? What about our child? It's fucked up that all my life I'm trembling to think about the future...For me, the only way out is to leave, to go to some normal country, so, you know, we keep on talking about the options. [Anna, non-biological mother]

\section{Who Am I? Patchworking the Image of Self in the Context of No Ready-Made Role Scripts}

One of the dilemmas identified in the narrationsespecially of those women who did not give birth to their children-is identity work in the context of conceptualizing oneself in relation to the role of the (other) mother. Therefore, to highlight their situation in the process of negotiating the image of self, it is worth referring to the issue of decoding the parent's status based on internalized concepts embedded in a wider socio-cultural context. Thus, it should be mentioned at this point that the traditional (and-in this sense-socially legitimized) understanding of the term "parenthood" is based on a silent assumption that such a social setting would consist of two figures-that of one mother and a father (Lubbe 2013). The question of how easy it is to decode the parent's status when a child is to be born seems to be relevant in the light of this assumption. While the changing body of a pregnant woman is an obvious indicator of becoming a mother, the social decoding of a man as a father usually comes due to noticing him alongside an expectant mother. Of course, the above considerations highlight the issue of comprehending motherhood in relation to, above all, its biological component, which, again, brings up the problem of building its meaning in the context of the socio-cultural norm of monomaternalism. In this sense, the figure of the other mother, which occurs in the family constellation next to the "true" one, seems to be conceptually invisible, which translates into the lack of a cultural frame of reference when embedding her in various interactional configurations (Wojciechowska 2015).

Agnes: When it was for sure, when we were certain Alex was pregnant it was like a huge WOW, I mean, don't even know...amazing, just an amazing feeling. I felt like I was to fly up to the sky! I was so proud that all I thought was to tell everyone that I was to be a mom!...We were not to tell anybody, but I eventually gave my mom a call. She was so happy, I mean, 'cause she knew what we've been through during the whole process...she said something like: "Congratulate Alex and give her big hugs," and all of the sudden there was this little pinch, “Mom, aren't you gonna congratulate me?" I said it more like a joke, you know, we were OK, like she said how much she loved us and stuff like that. But, it hit me pretty hard, you know. I mean, you usually say something like, congratulations to you both, you think of both parents, 
but here... I mean, will people ever see me this way? Wasn't so sure about that, you know.

Me: Then how did you expect to be seen?

Agnes: Absolutely no idea... I mean, when you see two ladies with a child, your first thought is there's a mom and somebody else, like an aunt maybe...Honestly, I expected people to be less tolerant than they actually are, but you know how it is-for the most part, they probably have no clue who we really are. [Agnes, non-biological mother]

The above narration excerpt illustrates the verbalized process of making meaning of oneself in the course of integrating diverse semantic strands, in which the subject seems to refer to such optics that she considers to be dominant in a specific socio-cultural context. Thus, it is worth following two interpretation paths: 1) contextualizing meaning within the heteronorm framework (due to its internalization) and 2) one's difficulties in referring to the ready-made (cultural) role scripts (of the other mother) at the level of both everyday functioning, as well as one's visibility in general, which the subject reconciles in the process of negotiating meaning that is given within the context of one's awareness of the common understanding of parenthood. Furthermore, in the process of identity narration, a specific context of suspicion arises-when the woman, expecting to experience at some point some form of social marginalization, sees her mother's utterance in terms of potential threat to her socially unrecognized status (that of a mother). As the informant's statement indicates, the emergence of the above-mentioned context of suspicion results from her failed attempt to unify alternative dimensions of understanding oneself as a mother (me in the role of the mother vs. me seen in the role of the mother). This manifests itself in anticipating the untranslatability of one's optics (referring to herself, the woman states who she is ["I was to be a mom"]) to the perspective of generalized other (referring to the anticipated social perception, she talks about who she is not ["I mean, will people ever see me this way?"]). Having the above in mind, it is worth noting here that one's acting within the context of suspicion may result in interpretational pitfalls. Since "they probably have no clue who we really are," people may act with no intention of discrediting anyone's status, especially when the social location at hand is invisible. On the one hand, acting so resembles what Barney Glaser and Anselm L. Strauss (1965) referred to as "suspected awareness" (when the patient suspects, but is not certain whether their illness is fatal, and thus endeavors to find out). On the other hand, it highlights to what degree the participants' anxiety and fear that they may not be seen as normal shape the way they make meaning (cf. Strauss 1959), which, in this sense, can be interpreted in terms of one of the defense mechanisms they adapt to protect oneself against anticipated emanations of homophobia. For instance, while accompanying the participants and their children at the time of doing observations, I have realized that, for the most part, they would interpret any form of unexpected interaction initiated by a stranger (e.g., gazes, smiles, small talk) in terms of unwanted (potentially threatening) or surprising (in case of positive reactions) events, as if the only social reaction they expected from people they did not know in case of revealing the nature of their family was rejection (see: Wojciechowska 2020).

Other interviewees have addressed the issue of conceptual invisibility in a similar vein when talking about experiencing the interactional marginalization of their status. The following excerpt from Mandy's narration exemplifies the situation of those informants who-while talking about the condition of 
their pregnant partners-experienced some "tension" in relation to understanding their interlocutors' utterances in terms of overlooking their experiences of becoming mothers. In this sense, such "tension" can be seen in terms of cognitive dissonance which arises as a result of confronting the perspective of one building her role with the dominant optics (heteronorm) that seems to exclude so doing from the horizon of meanings that are available to one's interlocutor(s).

So I thought about the guys, how it works for the guys, right, how it is in their case, and I guess, um, that's just how it's done, you know. Like, you look at that lady, and straight away you can tell she's pregnant, right. You see her pregnant belly; you see this big change going on [laughs]. Well, I guess it's not easy for the guys either [laughs]. Still, you know, it's a different situation, in a sense that you have a mom, you have a dad, and you have a crystal clear case. Nobody wonders what it means, um, if people don't ask me about those things, so... Sometimes you get so confused that you don't know what to think anymore. Need to talk to someone about it, to some guy, right [laughs], perhaps I'll figure out how I am supposed to feel about it [laughs].

The above utterance seems to illustrate the process of identity narration where giving meaning to one's situation takes place in the course of "filling" the conceptual gaps of one's invisible role with the meanings adapted from the anticipated interactional location of the socially conceptualized figure of the father. Thus, such an interpretative process seems to exemplify the fundamental difficulty in defining oneself by the subject, since it reflects a strong emphasis on the frame of meaning which describes non-heteronormative motherhood as an oxymoron. Furthermore, in the process of rationalizing the actions that she sees as marginalizing her status, the woman did not attempt to reframe (Goffman 1974) the meaning of her interactional location, but instead referred to such positioning through the prism of meanings embedded in the heteronorm, which cannot recognize her as a legitimate mother. Thus, the "filling" of conceptual gaps of one's invisible role with the meanings belonging with the heteronorm represents another interpretational pitfall. Still, it also exemplifies one's auto-work on identity (Konecki 2018).

\section{Making Oneself Visible: Identity Co-Work}

Since acting within the context of conceptual invisibility involves women in the vast amount of interpretative work they undertake to define oneself, it is worth stressing here how they make oneself visible in the process of identity co-work with their partners.

First, it should be noted that the process of making oneself visible can be seen through the prism of its symbolic dimension, regarding both those activities that are aimed at presenting the family (and oneself in it) overtly, as well as ventures whose implementation 1) enables symbolic "strengthening" of the family and 2) facilitates it to pass (Goffman 1986).

Agatha: We very much wanted to avoid any stressful situations, you know, we so much wanted to make sure that this very beginning of our motherhood, um, that no ambiguity is involved here. That's why we decided that Diana should give birth in a private clinic so anyone around knows [that the baby is ours].

Diana: We already had our contract signed.

Agatha: We both wanted to be $100 \%$ involved, make people know so there were no issues.

The above excerpt of narration illustrates how women-acting to protect oneself against "stressful situa- 
tions"-overcome the taboo of non-heteronormative motherhood, thusly laying the foundation for (co-) created scripts of an unconceptualized social role(s).

There was this long list [the nurse] brought so we could choose a donor. Some basic information like eye color, hair color, height...Also, some info on a person's education, age, a hobby even. So we had this pool of data from which to choose. We basically wanted a person that would physically resemble both of us. But, Joanna insisted on choosing a person that would look like I do. [Lisa, non-biological mother]

The actions verbalized above can be seen in terms of a symbolic response to one's inability to relate to their child in a dimension of motherhood different than social. In this sense, aiming for increasing the potential for physical similarity to one's offspring can be interpreted as a form of compensation in the area of the biological dimension of motherhood-the one "reserved" for family members related to the child by blood. Following the analytical path at hand, it is worth pointing to two potential consequences of so doing. First, acting thusly can be seen in terms of (more or less intentional) laying the foundation for symbolically "strengthening" the family relations, in the process of which the research participants may "outsmart" the imagined generalized other when it comes to decoding the dimensions of one's relationship with her child. Second, it is worth noting that one can see a certain practical value in acting so (in the context of its potential consequences)-one's physical resemblance to a child can help a woman to pass as the child's ("real") mother, and help her to avoid anticipated interactional hardships.

A crucial role in the process of identity narrationconducted by a woman who did not give birth to her child-is played by a biological mother who- through her actions-can facilitate her partner to project the family-based understanding of herself onto "external" (relative to the private sphere) areas of social reality. In this sense, the way women practice their family can be seen as one of the anchors based on which they conceptualize, as well as manage its visibility, but it also-by fitting together the lines of their actions-exemplifies how they support one another in the course of joint action (Mead 1934). Furthermore, due to overtly presenting their family relations, the women under study make conceptually invisible visible; and this allows them to go beyond the "safe haven" of their private lives.

We went to the clinic together, and there was this question, um, totally natural given where we were, "For how long have you and your [male] partner been trying to get pregnant?" So I said it was not the case, told him I was romantically involved with a woman and artificial insemination was the only choice I had. [Diana, biological mother]

Although acting within the context of anticipating some form of symbolic exclusion due to revealing a non-heteronormative identity, as long as they can resort to a certain (economic) capital-allowing them to symbolically control the interaction, most of the research participants tend to overtly present their family relations. Also, due to contributing to making symbolically visible both the role, as well as the status of a non-biological mother within the institutionalized social space, the after-effects of such actions-as interpreted by the informants-can be seen in terms of interactional success and, in this sense, allow the projection of specific patterns of acting onto wider areas of everyday life. Thus, it is worth mentioning here that the research participants perceive such a strategy in the context of managing stress, which could potentially occur due to 
hiding the (conceptual) presence of one of them. Of course, acting so would usually take place in a private clinic where-as clients-women can, to a large degree, control the course of an interaction.

\section{Concluding Remarks}

This article aims at highlighting the contexts and dimensions of the complexity of the situation of non-heteronormative mothers, especially those of them who did not give birth to their children. Therefore, two frameworks of meaning in relation to which women tend to embed their-often non-linear-streams of identity narration were elucidated, that is, complementary manifestations of the heteronorm as exemplified by the conceptual invisibility of (non)mothers-lesbians in the light of the law, as well as in the wider cultural context, where the understanding of motherhood is relativized to the ideological doctrine of monomaternalism. Bearing the above in mind, it is worth mentioning here that while the cultural phenomenon of conceptual invisibility-although actually experienced and, in this sense, luring women into "never-ending" conceptualizing of oneself-seems to complicate the situation of the informants concerning-above allthe semantic fields of (non)presence of (non)mothers-lesbians, the issue of their literal invisibility in legal regulations entangles them into a spiral of uncertainty, framed by the context of anxiety, and-in this sense-can be seen as (almost) tangible. For it is at this level of their everyday functioning where non-biological, non-heteronormative mothers experience-in a very painful way-their formally attested "foreignness" towards their children and partners. The situation at hand has an impact on their identity narration, in the process of which they may encounter interactional pitfalls, exemplified, for instance, by filling conceptual gaps in the scripts of their role(s) with the meanings they give to the anticipated interactional location of figures that are not similar to them. In this sense, the potential of "overcoming" such an interpretative deadlock seems to lie in the process of giving meaning to partners' (co-)actions aimed at making the family visible-if, of course, in the light of unfavorable socio-cultural conditions and marginalizing Polish law, the research participants will have resources and motivation (or-courage) to undertake such actions.

Of course, the problem of how non-heteronormative mothers make meaning of who they are should also be analyzed within a broader context of Polish society. First, the way women see themselves in the context of their roles is underpinned by internalized heteronormativity (see: CBOS 2017; 2019), which can be seen as a particular form of social control, thus exemplifying how traditional societies tend to stigmatize those who "have chosen" to go beyond the frame of heteronormativity. In this context, non-heteronormative mothers can be seen as "discreditable"-those who, although are aware of their stigma, can manage its visibility (Goffman 1959; 1986) and thus-avoid being decoded as "deviants." Second, the way they see themselves (and are seen) stands for the hypocrisies of the Catholic Church which-although refrains from (directly) framing homosexuality as a sin-do stigmatize same-sex relationships due to not recognizing them in terms of (normal) families (Lubbe 2013; Wycisk 2017). Third, initiatives such as "LGBT-free zones" sies that arose over the LGBT+ subject during the 2020 presidential elections in Poland, ${ }^{10}$ widely covered in the Polish and international media, seem

\footnotetext{
${ }^{9}$ See: https://www.nytimes.com/2020/07/30/world/europe/LGBTfree-poland-EU-funds.html. Retrieved September 20, 2020.

${ }^{10}$ See: https://www.bbc.com/news/world-europe-53039864. Retrieved September 20, 2020.
} 
to have deepened the mutual distrust between the parties creating the everyday realities for everyone involved, which can result in same-sex female families being more reluctant than before to reveal the nature of their relationships, and the normative society at large more persistent in opposing their right to live like (a normative) everyone else.

In light of referring to the context-specific heteronormative framework (see: Ryan-Flood 2009) to explain the situation of the study participants, one may ask whether the situation of those forming same-sex female families in a more favorable socio-legal-cultural climate is, indeed, significantly different from what Polish non-heteronormative mothers encounter. Of course, many issues, especially those concerning social mothers, may turn out to be quite similar to what the study participants face. For example, the issue of negotiating one's role in the family (see, e.g., Pelka 2009; Paldron 2014) or the one of challenging people's definition(s) of normality, which can translate into facing a variety of obstacles (see,

\section{References}

Abramowicz, Marta. 2010. "Wprowadzenie do problematyki raportu [Introduction to the Report]." Pp. 7-11 in Tęczowe rodziny w Polsce [Rainbow Families in Poland], edited by M. Zima. Warsaw: Kampania Przeciw Homofobii.

Berger, Peter L. and Thomas Luckmann. 1966. The Social Construction of Reality. Harmondsworth: Penguin Books.

Blumer, Herbert. 1969. Symbolic Interactionism. Englewood Cliffs, NJ: Prentice Hall.

Bos, Henny and Frank van Balen. 2008. "Children in Planned Lesbian Families: Stigmatisation, Psychological Adjustment and Protective Factors." Culture, Health E Sexualities 10(3):221-236. e.g., Bos and van Balen 2008; Mezey 2008; 2013), to name a few. In fact, being seen as lower down on the ladder of normalcy, as Warner (1999) framed it, is yet another social construct. Still, what seems to further complicate the situation of the study participants is that, in the case of Poland, the heteronormative culture-surfacing, among others, from social anxiety-is manifested in Polish law. And, as outlined in Polish-specific research on the subject at hand (see: Wojciechowska 2014; 2015; 2020; Mizielińska, Struz$i k$, and Król 2017), it is at this level of their everyday acting where two-mother families experience their marginalization-invisibility-most severely.

The above reflections draw attention to a number of barriers and challenges that two-mother families living in Poland face on a daily basis-while acting within a specific socio-cultural, but also legal context. In this sense, they allow the seeing of how, and for what reasons, two mothers of one child make sense of specific elements of their reality that fall within a broad spectrum of their everyday experiences.

CBOS. 2017. "Attitude to People of Homosexual Orientation." Retrieved July 27, 2020 (https://www.cbos.pl/PL/publikacje/ public_opinion/2017/12_2017.pdf).

CBOS. 2019. Stosunek Polaków do związów homoseksualnych [The Attitude of Poles towards Homosexual Relationships]. Retrieved September 20, 2020 (https://www.cbos.pl/SPISKOM. POL/2019/K_090_19.PDF).

Giddens, Anthony. 1991. Modernity and Self-Identity. Stanford, CA: Stanford University Press.

Glaser, Barney and Anselm L. Strauss. 1965. Awareness of Dying. Chicago: Aldine Publishing. 
Glaser, Barney and Anselm L. Strauss. 1967. The Discovery of Grounded Theory: Strategies for Qualitative Research. New York: Aldine Publishing.

Goffman, Erving. 1959. The Presentation of Self in Everyday Life. Garden City, NY: Doubleday.

Goffman, Erving. 1974. Frame Analysis. Cambridge, MA: Harvard University Press.

Goffman, Erving. 1986. Stigma. New York: Touchstone.

Kleinknecht, Steven. 2007. "An Interview with Robert Prus: His Career, Contributions, and Legacy as an Interactionist Ethnographer and Social Theorist." Qualitative Sociology Review 3(2):221-288.

Konecki, Krzysztof T. 2000. Studia z metodologii badan jakościowych. Teoria ugruntowana [Studies in Qualitative Methodology. Grounded Theory]. Warsaw: Wydawnictwo Naukowe PWN.

Konecki, Krzysztof T. (2018) Advances in Contemplative Social Research. Lodz: Wydawnictwo Uniwersytetu Łódzkiego / Cracow: Wydawnictwo Uniwersytetu Jagiellońskiego.

Lubbe, Carien. 2013. "LGBT Parents and Their Children: Non-Western Research and Perspectives." Pp. 209-223 in LGBT-Parent Families, edited by A. E. Goldberg, K. R. Allen. New York, Heidelberg, Dordrecht, London: Springer.

Majka-Rostek, Dorota. 2014. “Macierzyństwo lesbijek - wybrane konteksty społeczne [Lesbian Motherhood-Selected Social Contexts]." Studia Socjologiczne 215(4):59-76.

Mead, George H. 1934. Mind, Self, and Society from the Standpoint of a Social Behaviorist. Chicago: University of Chicago Press.

Mezey, Nancy J. 2008. New Choices, New Families: How Lesbians Decide about Motherhood. Baltimore, MD: The Johns Hopkins University Press.

Mezey, Nancy J. 2013. "How Lesbians and Gay Men Decide to Become Parents or Remain Childfree." Pp. 59-70 in LGBT-Parent Families. Innovations in Research and Implications for Practice, edited by A. E. Goldberg and K. R. Allen. New York, Heidelberg, Dordrecht, London: Springer.

Mizielińska, Joanna, Marta Abramowicz, and Agata Stasińska. 2014. Rodziny z wyboru w Polsce [Families of Choice in Poland]. Warsaw: Instytut Psychologii Polskiej Akademii Nauk.
Mizielińska, Joanna, Justyna Struzik, and Agnieszka Król. 2017. Różnym głosem. Rodziny z wyboru w Polsce [In a Different Voice. Families of Choice in Poland]. Warsaw: Wydawnictwo Naukowe PWN.

Paldron, Morgan. 2014. The Other Mother: An Exploration of Non-Biological Lesbian Mothers' Unique Parenting Experience. PhD Dissertation. University of Minnesota, Minneapolis.

Park, Shelly M. 2013. Mothering Queerly, Queering Motherhood. Albany, NY: State University of New York Press.

Pelka, Suzanne. 2009. “Sharing Motherhood: Maternal Jealousy among Lesbian Co-Mothers." Journal of Homosexuality 56(2):195-217.

Prus, Robert. 1997. Subcultural Mosaics and Intersubjective Realities. An Ethnographic Research Agenda for Pragmatizing the Social Sciences. Albany, NY: State University of New York Press.

Prus, Robert and Scott Grills. 2003. The Deviant Mystique. Westport, CT: Praeger.

Ryan-Flood, Róisín. 2009. Lesbian Motherhood: Gender, Families and Sexual Citizenship. Basingstoke: Palgrave Macmillan.

Schütz, Alfred. 1962. “On Multiple Realities.” Pp. 207-259 in Collected Papers, Vol. I: The Problem of Social Reality, edited by M. Natanson. The Hague: Martinus Nijhoff.

Strauss, Anselm. 1959. Mirrors and Masks. Glencoe, IL: Free Press.

Turner, Ralph. 2001. “Role Theory.” Pp. 233-254 in Handbook of Sociological Theory, edited by J. Turner. New York: Springer.

Warner, Michael. 1999. The Trouble with Normal. Cambridge, MA: Harvard University Press.

Wojciechowska, Magdalena. 2014. “Uczenie się 'normalności' w sytuacji doświadczania symbolicznego wykluczenia - przykład badań nad rodzicielstwem jednopłciowym kobiet w społeczeństwie heteronormatywnym [Acquiring the Sense of 'Normality' within the Context of Experiencing Symbolic Exclusion-The Case of Study on Same-Sex Female Parenting in Heteronormative Society]." Studia Socjologiczne 214(3):127157.

Wojciechowska, Magdalena. 2015. “O działaniu w ramach konceptualnej niewidzialności. Przykład badań nad macierzyń- 
stwem jednopłciowym w doświadczeniu matek niebiologicznych [Acting within the Context of Conceptual Invisibility. How Non-Biological Lesbian Mothers Experience Motherhood]." Przegląd Socjologii Jakościowej 11(4):114-145.

Wojciechowska, Magdalena. 2020. Dwie matki jednego dziecka [Two Mothers of One Child]. Lodz: Wydawnictwo Uniwersytetu Łódzkiego.
Wycisk, Jowita. 2017. “Heteroseksizm i jego znaczenie dla pracy psychologicznej z rodzinami LGB. Sytuacja w Polsce [Heterosexism and Its Significance for Psychological Work with LGB Families. The Situation in Poland]." Psychologia Społeczna 12(4[43]):415-429.

Zimbardo, Philip. 2007. The Lucifer Effect. New York: Random House.

\section{Citation}

Wojciechowska, Magdalena. 2020. "How Non-Heteronormative Mothers Negotiate Meaning: Experiencing and Contextualizing Invisibility." Qualitative Sociology Review 16(4):146-163. Retrieved Month, Year (http://www.qualitativesociologyreview.org/ ENG/archive_eng.php). DOI: http://dx.doi.org/10.18778/1733-8077.16.4.09 